\title{
Adapting Agriculture to Climate Variability and Change: Capacity Building Through Technological Innovation
}

\author{
Netra B. Chhetri \\ School of Geographical Sciences \& Urban Planning \\ Consortium for Science, Policy, \& Outcomes, \\ Arizona State University, Tempe, AZ,
}

USA

\section{Introduction}

Agricultural adaptation is an ongoing and dynamic process through which agrarian societies adapt to changing socioeconomic, technological, and resource regimes. Historically farmers have learned to thrive in a wide range of climatic conditions, ranging from extreme cold to hot temperature and from very dry to humid climate (Easterling et al., 2004). Variations in climatic resources across space and time have also acted as source of technological and institutional innovations (Hayami and Ruttan, 1985; Chhetri and Easterling, 2010). Human managed systems are continually responding to climatic conditions (Jodha, 1978), exhibiting their inherent potential for adaptation to future climate change. Examples of agricultural adaptation to climate also include translocation of crop across thermal gradients (Easterling, 1996; Gitay et al., 2001), substitution of new crops for old ones (Smithers and Blay-Palmer, 2001) and innovation of technologies to alleviate climatic constraints (Chhetri and Easterling, 2010).

Agricultural adaptation to emerging threat brought about by changing climate is entirely a different matter. Climate variability and change, especially the extremes, may create a new level of risks outside the realm of past experiences such as more frequent and extensive drought, abrupt break in seasonal rainfall, and extreme heat (Adger et al., 2007). It appears important, therefore, to seek to enhance the capacity of farmers to respond and adapt to such impacts of climate change. Agricultural adaptation, however, can be undertaken by range of stakeholders including farmers, public institutions, communities, civil society (NGOs) and private sectors. A sustained effort to adaptation in agriculture therefore demands an active engagement of various stakeholders so that location-specific technology is innovated to adapt to climate change.

While studies consistently show that climate change may not imperil the ability of world's agriculture to maintain food security in the short term (Gitay et al., 2001, Fischer et al., 2005, Easterling et al., 2007), it may challenge farmers to adapt in regions where it could be stressful and where new climate-induced opportunities remain unanswered. Agricultural adaptation, as a response to climate change, is contingent upon various factors including agro-ecological thresholds; values and cultural norms; agricultural policies and markets; 
and the availability of technological choices for farmers (Reilly et al, 1996; Heyd and Brooks, 2009; Chhetri and Easterling, 2010).

Technology can potentially play an important role in adaptation in agriculture, yet much of what is known about the process of technological innovation in agriculture has yet to be captured in discussions of climate change adaptation. The time may now be opportune for a much broader debate on how technology might help adapt. This paper begins by discussing the role of technology in modern agriculture to illustrate the means through which society may respond to minimize the impacts of climate change in agriculture. This is followed by discussion of the values of climatic sensitive technological innovation in agricultural adaptation in the future. More specifically this section argues need for a close coupling of climate and technology so that location-specific technologies are delivered to and adopted by farmers. Fourth section illustrates the importance of understanding adaptations through analogy so that effectiveness of the adaptations practices to past climatic extremes across space and time can be examined. While the examples of farmers' response to extreme events of the past may not be directly applicable to a future adaptation, the insight may be gained about how the adaptation process may unfold in the future. In section five the premise of the hypothesis of induced innovation is discussed as it suggests an important pathway for the interaction of climate and technology and for the study of the agricultural adaptation to climate variability and change. The concluding section of this paper emphasizes the significance of technological innovation in agricultural adaptation in the future.

\section{Role of technology in modern agriculture}

While climate change poses a fundamental challenge often outside the range of current and past experiences, it is reasonable to expect that farmers and their supporting institutions would respond to new crop growing environments brought about by climate change the same way they have responded to climatic limitations of the past (Chhetri and Easterling, 2010). Insights for agricultural adaptation that confront us today may well be found in the experience of handling climatic challenges across various regions. Yet the science of adaptation has not progressed to the point where we have fair understanding of factors that enables smooth adaptation to new climate of the future. Much of what is known about the process of technological innovation has yet to be captured in discussions of agricultural adaptation to climate change. It is true that technological innovation in agriculture does not evolve with respect to climatic conditions alone; non-climatic forces, such as market and other social factors, clearly play a significant role. Yet research efforts in understanding the processes of technological change driven by climatic factors are pivotal to make any assertion about likely adaptation of agriculture to climate change.

Innovation, a process through which new (or improved) technologies are developed and brought into widespread use, have been, and will continue to be, central to adapting to climate change. For example, not only new and improved agricultural technology is crucially needed to adapt to changing climatic means and associated variability, it is also a solution space for addressing the food security challenge of ever growing population of the world. Additionally, new and carefully designed technologies may enable society to increase their robustness to tackle the emerging challenges emanating from climate and other ongoing changes. Innovation of technologies, however, is a nonlinear process. It is the 
product of constant interaction and feedback between social space (where individual interact) and organizational space mediated by infrastructure wherein individual and institutions operate. Therefore technological innovation involves the engagement of institutions and individuals in this space that cannot be trivialized. Depending on the nature and type, the process of technological innovation involved different institutional arrangement. In agricultural systems, for example, technological innovation has resulted in a more complex and sophisticated human-environment relationship in rice production. According to Chhetri and Easterling (2010), research establishment Nepal has used climate as one of the drivers of research and development of technologies in agriculture whereby multiple stakeholders, including farmers and NGOs, have worked together to develop technologies that consider local needs and climatic conditions.

A study by Smithers and Blay-Palmer (2001) also shows the role of farmers and their supporting institutions in alleviating the constraints of climate to soybean in Canada. A fundamental climatic constraint to soybean cultivation in Ontario, Canada was the prevalence of cold night temperature during its flowering period, confining soybean cultivation to the extreme southwestern portion of the province. A key innovation to address this constraint was the introduction of cold-tolerant genetic material, Fiskeby63, from Sweden that led to the development of Maple Arrow cultivar that eventually played a vital role in the eastward spread of soybean crop. Between 1970 and 1997, the total acreage planted to soybean increased by over 500 percent, with the expansion being attributed to a series of technological innovations made in response to the climatic condition of Ontario (Smithers and Blay-Palmer, 2001). According to Smithers and Blay-Palmer (2001), technological innovations were not only confined to development of cultivars but also to a range of agronomic activities including modification of planting time and crop rotation interrupted pest cycle enhancing the cultivation of soybean.

The development of cowpea cultivars in the African Sahel illustrates the example of technological substitution in response to existing variability in climatic resources. To escape the effects of drought, scientists in the African Sahel developed early maturing cowpea cultivars with different phenological characteristics. To avoid the effects of late season drought, they developed two cowpea varieties (Ein El Gazal and Melakh) that mature between 55 - 64 days after planting (Elawad and Hall, 2002). Similarly, to avoid mid-season drought, scientists also developed a cowpea variety (Mouride) that matures between 70-75 days after planting (Cisse et al, 1997). Unlike Ein El Gazal and Melakh, that begin flowering between 30-35 days from sowing and have synchronous flowering characteristics, the Mouride variety starts flowering in about 38 days after planting and spreads out over an extended period of time, thereby escaping the midseason drought. Additionally, to enhance the chances of significant grain production, agriculturists in this region developed an innovative cropping technique where both types of cowpea (short and medium maturing) are planted together so that the climatic input is optimized (Hall, 2004). Infrastructural innovation like the development of efficient irrigation infrastructure has been very effective in stimulating growth in agricultural production (Pinstrup-Andersen, 1982). In South and Southeast Asia, outcomes of the Green Revolution, characterized by development and diffusion of high yielding varieties (HYVs) of food crops, made possible by the availability of irrigation water, and early maturing HYVs facilitated by wider distribution of chemical fertilizers to maintain productivity, are considered to be positive developments, despite criticisms regarding distributional inequities and environmental concerns (Evenson and Gollin, 2000). 


\section{Sensitivity of technology to climate}

Sensitivity of technological innovation to climate can serve as a potent means to adapt to progressively changing climatic mean and variability. The crux of the problem is whether or not climate variability and change serves as a driver of appropriate technological change. While ongoing research on climate change and agriculture is deepening the level of understanding, much of what is known about the process of technological innovation in agriculture has yet to be captured in discussions of climate change adaptation (Chhetri and Easterling, 2010). While non-climatic forces, such as market and other social factors, clearly play a significant role (Brush and Turner, 1987; Liverman, 1990), research efforts in understanding the processes of technological change driven by climatic factors are pivotal to making any assertion about likely adaptation of agriculture to climate change (Rosenberg, 1992). For example, research shows that the patterns of technological innovation in agriculture have generally served to reduce the dependence on the scarcest resources in each country where high rates of productivity growth have been observed during the $20^{\text {th }}$ Century (Hayami and Ruttan, 1985). This experience suggests that if climate change causes a change in resource scarcities, public institutions do have some capacity to respond to those evolving scarcities. It is important to note here that for the assessment and analysis of climate adaptation, much of the agricultural technology that was developed in response to resource scarcity has been largely ignored. It is crucial to understand how climate and technology are interacting in agriculture so that a reasonable prognosis can be made about the possible adaptation to impending challenges of climate change.

Climate-technology interaction occurs when location-specific technologies are delivered to and adopted by farmers to address climatic limitations or opportunities in crop growth and development. This interaction is vital because greater crop yield is desired by all farmers regardless of the range of climatic conditions in which they farm. For example, an optimal cultivation of rice is possible only when climatic conditions are favorable that invariably means an inadequate supply of climatic resources (e.g. rainfall) adversely affects productivity. It is important therefore to understand how climatic limitations provide incentives for farmers to urge the institutions that support them to invest in research and development of location-specific technologies that substitute for climatic scarcity. The implication of this assertion is that regions that do not have location-specific technologies and/or infrastructure in place would not be able to cope and adapt to the changing future climate.

Translating this argument, as presented in the conceptual model (Figure 1), the induced innovation hypothesis suggests an important pathway for the interaction of climate and technology and for the study of the agricultural adaptation to climate change. The next section this paper will take the discussion further to include the role of technological change in climatic adaptation through the conceptual framework of the hypothesis of induced innovation. The justification for this approach is built on the premise that in order to know how well society might be prepared to adapt to changing climatic conditions, it is important to understand how well society has instituted technologies to address uncertainties emanating from climatic and other livelihoods stressors in the past, and consequently to minimize the risks associated with it. In addition, exploring the ways in which climatic uncertainties (unknown) induce or hinder technological innovations as means to respond to climatic constraints can have important implications for the analysis of agricultural adaptation in the future. 


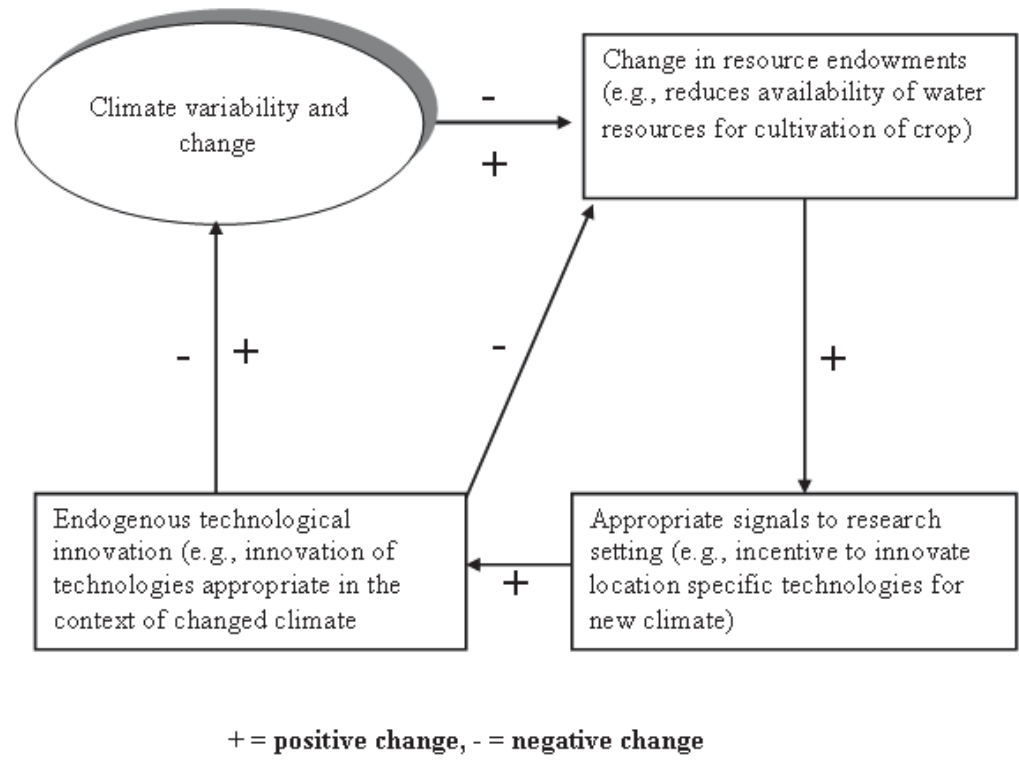

Fig. 1. Induced technological and institutional innovations: a conceptual perspective.

\section{Understanding adaptation by analogy}

One of the challenges in understanding the impacts of climate change on agriculture is gaining insights of how farmers and their supporting institutions interact to adapt to changing climatic conditions. Understanding adaptations through analogy may help evaluate the effectiveness of potential adaptation strategies by comparing observed adaptations to past climate extremes across space and time. Usually events that have had a similar effect in the recent past are compared to the likely impact of future events associated with climate change, assuming that lessons can be learned from such past experience and then applied to future situations. Although an example of adaptation in one place at a particular time is not always applicable to a future adaptation at a different place, the insight may be gained about how the adaptation process may unfold in the future.

Analogues of technological innovation in agriculture and their relevance to climate change and adaptation include deliberate translocation of crops across different agro-climatic zones, substitutions of new crops for old ones, and substitutions of technology induced by scarcity of resources. Examples of crop translocation include thermal expansion of hard-red winter wheat in the Great Plains region of the United States and Canadian Prairie (Rosenberg 1992), and the expansion of the northern boundary of winter wheat in China, aided by the introduction of freeze-resistant varieties from Russia and Canada (Lin 1997, Chen and Libai, 1997). According to National Research Council (NRC, 1999), adaptation of canola in Canadian agriculture in the 1950s and 60s also shows the rapidity with which farmers and their supporting institutions adapt to market signals. 
In response to the reduction of a frost-free growing season, farmers in Australia have modified their choice of cultivars in wheat (Meinke et al., 2003). For example, in Central Queensland, the average frost period shrunk from approximately 80 days at the end of $19^{\text {th }}$ century to about 17 days at the end of $20^{\text {th }}$ century. In response to such a change in growing season length, wheat in this region is sown earlier than they were in the 1950s and 1960s, targeting flowering dates of early to mid August to maximize grain filling period. Likewise farmers in the semiarid tropics of Kenya and Ethiopia have been able to increase water use efficiency through a combination of water harvesting techniques and drip irrigation that have enabled them to diversify cropping systems and minimize risk from increasing drought spells and erratic rainfall pattern (Ngigi et al., 2000). These examples provide evidence of adaptive research specifically targeted to address location-specific climatic needs. Yet, notwithstanding this recognition, there is a dearth of research that explains the role of climate as a stimulus for innovation of appropriate technologies (Ruttan, 1996).

\section{Agricultural adaptation and the hypothesis of induced innovation}

For the purpose of this paper, the term agricultural adaptation, following Easterling et al. (2004), refers to the actions that farmers and their supporting institutions take to reduce impacts or take advantage of new opportunities that may arise as a result of climate and other ongoing changes. Nearly two decades of research show that without adaptation, climate change is generally problematic for agricultural production (e.g., Reilly et al., 1996; Gitay et al., 2001; Easterling et al., 2007). Adaptation, in general, may lessen future yield losses (Easterling et al., 2007) or may improve yield gain in regions where new opportunities brought about by changing climate (e.g. extended growing season) have been seized upon. An overall synthesis by the Assessment Report Four (AR4) of the Intergovernmental Panel on Climate Change (IPCC) that plotted yields of three cereal crops (rice, wheat, and maize) against degrees of average local warming and associated changes in $\mathrm{CO}_{2}$ shows that moderate to medium change in local temperature $\left(1-3^{\circ} \mathrm{C}\right)$ could have a small positive effect in yield in mid-to high-latitude regions. In the low-latitude regions simulation studies showing even moderate temperature change $\left(1-2^{\circ} \mathrm{C}\right)$ would likely have a negative effect on crop yields (Easterling et al., 2007). Although vulnerability of agriculture, defined here as the extent to which change in climate may damage food production from climate change net of adaptation, is greater in developing countries as compared to the developed countries, in both cases adaptation clearly ameliorates losses in yield. This reasoning has made the case for adaptation even stronger with clear indications that adaptation can only be ignored to the detriment of food security.

Articulated by Hayami and Ruttan in the early 1970s, the hypothesis of induced innovation has earned wide recognition in the field of agricultural development. It refers to the process by which societies develop technologies that facilitate the substitution of relatively abundant factors of production for relatively scarce factors in the economy. The hypothesis posits that the development of new technologies in agriculture is a continuing process induced by differences in the relative scarcity of resources, and is signaled by change in resource endowments. Furthermore, this hypothesis has emerged as a basis for understanding potential future agricultural adaptation to climate variability and change. Study by Chhetri and Easterling (2010) show an evidence of climate-induced innovation supporting the assertion that if farmers and public institutions are engaged in "co-production" of agricultural technologies, they are able to respond to climatic challenges much more readily 
than would have been possible otherwise. It is reasonable, therefore, to argue that the process of technological change represents an essential element of agricultural adaptation to climate change. As shown in Figure 1, climate change may alter these climatic resources by changing growing season length and soil moisture regimes, and by adding heat stress to the plant. Such changes, following the hypothesis of induced innovation, will provide appropriate signals to farmers and public institutions to induce technologies suitable for the new environment. Eventually, farmers and their supporting institutions will develop technologies to avoid the deleterious effects of climate change in agriculture. Some of these new technologies, however, may have positive feedback to climate systems and other could have negative feedback. The strength of this simple framework lies in its ability to highlight the central role of climate as a motivator of technological innovation and ultimately as a source of adaptation. Within this conceptual framework, it is important to examine the role of spatial and temporal variability in climate as an incentive to the innovation of technologies.

The hypothesis of induced innovation gained prominence with the publication of Yujiro Hayami and Vernon Ruttan's book, Agricultural Development: An International Agricultural Perspective in 1971 and 1985. In their work Hayami and Ruttan (1985) provide a powerful insight into the process of technological innovation in agricultural development. An important revelation into their analysis is the decomposition of changes in output per unit of labor into change in output per unit of land. These two factors of production are seen as "relatively independent" and associated with two different paths - one typified by the experience of the United States where progress in mechanical technology facilitated the substitution of power for human labor, and the other typified by the Japanese experience, where the progress in biological technology increased the productivity of land (p. 171).

The different paths of technological change in agriculture for the U.S. and Japan were shaped by differences in relative scarcity of resource endowments (labor and land). Throughout the period of 1880-1980 Japanese farmers used more fertilizer per hectare than the U.S. farmers. The U.S. farmers, in turn, used more machinery per worker than the Japanese farmers. In Japan, where land is relatively scarce, it was progress in biological technologies that led to increased response of rice varieties for higher level of fertilizer application. But in the U.S., where labor is a relatively scarce factor, it was the process of mechanization, first with animal and later with farm machinery (e.g., combine harvester), which facilitated the expansion of agricultural production by increasing the area operated per worker. In both cases, a process of dynamic adjustment to change in resource endowment was achieved through the innovation of appropriate technology.

To date, the hypothesis of induced innovation has been used to explain the relationship between resource endowment and the development of new technologies. There is now a substantial body of literature documenting the process of induced technological change in both developed and developing countries, and particularly the development of alternative technological trajectories to facilitate the substitution of relatively abundant factors for relatively scarce ones (e.g. Thirtle and Ruttan, 1987; Islam and Taslim, 1996; Thirtle et al., 1998). Studies on land and labor productivities for a broad range of counties and major geographic regions are broadly consistent with the hypothesis of induced innovation.

While the hypothesis of induced innovation has been credited with responding appropriately to the factor of production in agriculture, the role of climate as a stimulant for technological innovation remains largely unexplored. Little is known about the manner in 
which technology has altered the relationship between climate and society and the roles that climate has played in development of the new innovations. The interaction between climate and technology depends upon whether new technology encourages capital to be a complement or a substitute for climate (Mendelsohn et al., 2001). For example, if the marginal productivity of technology is higher for farms in an ideal climate, technology and climate could complement each other. In this case, technology is targeted to the ideal climate, making farmers in this environment more productive than farmers in marginal locations. However, if marginal productivity of technology is equal or better in a relatively unfavorable climate compared to the favorable one, then technology is said to have substituted for climate. Following the assertion made by the hypothesis of induced innovation, this is a desired condition if agriculture is to adapt to changing climatic resources in the future.

Although future climate is uncertain, the critical issue is how the research establishment has perceived the scarcity of climatic resources and how has this perception allowed them to integrate their attempts to innovate technology needed for farmers to respond to the evolving climate. Thus, the perception of resource scarcity, in this case climate, enters the Research and Development (R\&D) process through interaction between farmers and the public institutions responsible for generating technologies. In the context of climate, mechanical innovations include irrigation, conservation tillage, leveled terracing, and integrated drainage systems - all of which are essential to widen agricultural activities that existing climatic resources would have, otherwise, not permitted. Biological innovations, on the other hand, also have significant roles in enabling agriculture to adapt to a wider range of climatic conditions. For example, through investment in crop-improvement programs, societies can develop varieties that are resistant to pest and diseases or tolerant to heat and drought, all pivotal in ameliorating the impact of climate change. If the farmers and their supporting institutions have not acquired the capacity to innovate technologies specific to their resource endowments, they will find it difficult to adapt to new and emerging climate. At its core, agricultural adaptation is about the capacity of all stakeholders to shift strategies to develop food production systems that are robust enough to withstand change driven by climate and other stressors.

\section{Conclusion}

The IPCC AR4 (IPCC, 2007) concludes that the Earth is committed to at least as much warming over the next 90 years as was experienced in the $20^{\text {th }}$ century, even if greenhouse gas emissions were immediately curtailed to 2000 levels. This means that agricultural adaptation to climate change is inevitable. Studies conducted over two decades have identified a range of potential agricultural adaptations options for farmers. Most of these are extensions of existing risk management activities such as alteration of planting times to avoid temperature stress during critical plant growth and development stage, targeted irrigation to reduce water stress, and breeding of drought resistant cultivars. Some of these have been assessed as having substantial potential to offset negative effects of climate change. However, there has been little evaluation of how effective these and other adaptations may be given the complex nature of farm decision-making, the likely diversity of responses within and between regions, the possible interactions between different adaptation options, and the economic, institutional and cultural barriers to change. 
According to the hypothesis of induced innovation, advances in knowledge can permit the substitution of more abundant resources for increasingly scarce resources to reduce the constraints for agricultural production. For example, innovation of early maturing cultivars has the greater potential of escaping the effects of drought that would be increasingly important to address the limitation of water scarcity due to a change in rainfall pattern. This may be done through the development of crop varieties that can perform even better with short supplies of water; through employment of water conserving techniques, such as conservation tillage farming; and/or through the development of efficient irrigation techniques, such as drip irrigation that maximizes the use of available water. In response to inadequate and or unreliable precipitation, it is reasonable to assume the same responses from farmers and their supporting institutions (Glantz and Ausubel, 1988). Characteristics of ongoing mechanisms used by farmers and their supporting institutions to manage their agricultural systems do provide information about the processes by which future adaptation may take place in the face of climate change.

If the systems of food production is thriving, either because farmers and their supporting institutions are modifying their strategies in ways that respond to emerging changes or because the underlying systems on which their livelihoods are based are sufficiently flexible to absorb the impact of climate changes, then both are considered to be robust. Yet, the current trend of weaning resources away from agricultural and climate research, especially in developing countries, endangers the vital support provided by public institutions for farmers to adapt to climate change. Therefore, agricultural adaptation to future climate is contingent upon continued investment in agriculture, as well as active engagement of public institutions responsible for developing and disseminating appropriate technologies for farmers operating in specific climatic regions. Successful adaptation involves a dynamic process of adjustment to resource endowment created by a new and changing climate. I argue that if research establishment and farmers have made appropriate responses to improve their capacity to respond to climatic constraints then they are generally better prepared to adapt to changing climate.

\section{References}

Adger, W.N., S. Agrawala, M.M.Q. Mirza, C. Conde, K. O’Brien, J. Pulhin, R. Pulwarty, B. Smit and K. Takahashi, 2007: Assessment of adaptation practices, options, constraints and capacity. Climate Change 2007: Impacts, Adaptation and Vulnerability. Contribution of Working Group II to the Fourth Assessment Report of the Intergovernmental Panel on Climate Change, M.L. Parry, O.F. Canziani, J.P. Palutikof, P.J. van der Linden and C.E. Hanson, Eds., Cambridge University Press, Cambridge, UK, 717-743.

Adger, W. N., Eakin, H. \& Winkels, A. (2009). Nested and teleconnected vulnerabilities to environmental change. Frontiers in Ecology and the Environment, 7:150-157. Brush, S.B. and B.L. Turner, 1987. The nature of farming systems and views of their change. In: Turner B.L. and S.B. Brush (Eds.), Comparative Farming. The Guilford Press, New York, pp 11-48.

Brush, S.B. and B.L. Turner, 1987. The nature of farming systems and views of their change. In: Turner B.L. and S.B. Brush (Eds.), Comparative Farming. The Guilford Press, New York, pp 11-48. 
Chen, H. and H. Libai, 1997: Investigating about varieties filtering in winter wheat northward shifting. Journal of Chenyang Agricultural University, 28:175-179.

Chhetri, N. and W.E. Easterling. 2010. Adapting to climate change: retrospective analysis of climate technology interaction in rice based farming systems of Nepal. Annals of the Association of American Geographers 100(5):1-20. DOI: 10.1080/00045608.2010.518035.

Cisse, N., Ndiaye, M., Thiaw, S., Hall, A.E., 1997. Registration of 'Mouride' cowpea. Crop Science, 35:1215-1216.

Easterling, W.E., 1996. Adapting North American agriculture to climate change in review, Agricultural and Forest Meteorology, 80:1-53.

Easterling, W.E., H.H. Brian, and J.B. Smith, 2004. Coping with global climate change: the role of adaptation in the United States. Pew Center on Global Climate Change, pp. 40.

Easterling, W.E., P.K. Aggarwal, P. Batima, K.M. Brander, L. Erda, S.M. Howden, A. Kirilenko, J. Morton, J.-F. Soussana, J. Schmidhuber and F.N. Tubiello. 2007. Food, fibre and forest products. Climate Change 2007: Impacts, Adaptation and Vulnerability. Contribution of Working Group II to the Fourth Assessment Report of the Intergovernmental Panel on Climate Change, M.L. Parry, O.F. Canziani, J.P. Palutikof, P.J. van der Linden and C.E. Hanson, Eds., Cambridge University Press, Cambridge, UK, 273-313.

Elawad, H.O.A. and A.E. Hall, 2002. Registration of 'Ein El Gazal' cowpea. Crop Science, 42:1745-1746.

Evenson, R.E. and D. Gollin, 2000. The Green Revolution: End of Century Perspective. Paper Presented for the Standing Project on Impact Assessment of the Technical Advisory Committee of the Consultative Group on International Agricultural Research (CGIAR). New Haven, Connecticut, U.S. Economic Growth Center, Yale University.

Fischer, G., Shah, M., Tubiello, F., and van Velthuizen, H. 2005. Socio-economic and climate change impacts on agriculture:An integrated assessment, 1990-2080. Philosophical Transactions of Royal Society B, 360:2067-83.

Gitay, H., Brown, S., Easterling, W. and Jallow, B. 2001. Ecosystems and their Goods and Services. In Climate Change 2001: Impacts, Adaptation, and Vulnerability, Eds. McCarthy, J. pp. 235-342. Contribution of Working Group II to the Third Assessment Report of the Intergovernmental Panel on Climate Change, Cambridge University Press.

Glantz, M.H. and J. H. Ausubel, 1988. Impact Assessment by Analogy: Comparing the Impacts of the Ogallala Aquifer Depletion and $\mathrm{CO}_{2}$-Induced Climate Change. In Societal Responses to Regional Climatic Change: Forecasting by Analogy, Eds. Glantz, M.H, pp.113-142.Boulder, Westview Press,

Hall, A.E., 2004. Breeding for adaptation to drought and heat in cowpea. European Journal of Agronomy. Available online @ www.sciencedirect.com.

Hayami Y. and V W. Ruttan, 1971. Agricuitural development: an international perspective. The John Hopkins University Press, Baltimore, pp. 367.

Hayami, Y. and Ruttan V. W., 1985. Agricultural development: An international perspective. The John Hopkins University Press, Baltimore, pp. 506. 
Heyd, T. and N. Brooks, 2009. Exploring cultural dimensions of adaptation to climate change. In N. Adger, I. Lorenzoni, and L. O'Brien (Ed.), Adapting to Climate Change: Thresholds, Values, Governance (pp 269-282). Cambridge, UK: Cambridge University Press.

Islam, T. and M. A. Taslim, 1996. Demographic Pressure, Technical Innovation and Welfare: The case of the agriculture of Bangladesh. The Journal of Development Studies, 32, 734-770.

Jodha, N.S., 1978. Effectiveness of farmers' adjustment to risk. Economic and Political Weekly, 13:A38-A48.

Lin, E., 1997. Modeling Chinese agricultural impacts under global climate change. Chinese Agricultural Science and Technology Press, Beijing, China, pp: 61-68

Liverman, D.M., 1990. Drought impacts in Mexico: climate, agriculture, technology, and land tenure in Sonora and Puebla. Annals of the Association of American Geographers, 80:49-72.Meinke, H., W. Wright, P. Hayman, and D. Stephens 2003. Managing cropping systems in variable climates. In Principles of field crop production (IV Edition), Eds. Pratley J. pp. 26-77. Oxford University Press, Melbourne, Australia.

Meinke, H., W. Wright, P. Hayman, and D. Stephens 2003. Managing cropping systems in variable climates. In Principles of field crop production (IV Edition), Eds. Pratley J. pp. 26-77. Oxford University Press, Melbourne, Australia.

Mendelsohn, R., A. Dinar, A. Singh, 2001. The effect of development on the climate sensitivity of agriculture. Environment and Development Economics, 6:85-101.

National Research Council (NRS), 1999. Human dimensions of global environmental change: Research pathways for the next decade. National Academy Press, Washington D.C. pp. 83.

Ngigi, S.N., J.N. Thome, D.W. Waweru, and H.G. Blank, 2000. Technical evaluation of low-head drip irrigation technologies in Kenya. Research report, Nairobi University and the International Water Management Institute (IWMI), Nairobi, pp. 21.

Pinstrup-Andersen, P., 1982. Agricultural Research and Technology in Economic Development. New York, Longman.

Reilly, J., 1996. Agriculture in a changing climate: Impacts and adaptations. In Houghton, J. T., L. G. Meiro Filho, B. A. Callander, N. Harris, A. Kattenberg, and K. Maskell, eds, Climate Change 1995: The Science of Climate Change. Contribution of Working Group I to the Second Assessment of the Intergovermental Panel on Climate Change. Cambridge University Press, Cambridge, pp. 584.

Rosenberg, N.J., 1992. Adaptation of agriculture to climate change. Climatic Change. 21:385405.

Ruttan, V.W., 1996. Research to achieve sustainable growth in agricultural production into the 21st century. Canadian Journal of Plant Pathology. 18:123-132.

Smithers, J. and A. Blay-Palmer, 2001. Technology innovation as a strategy for climate adaptation in agriculture. Applied Geography, 21:175-197.Thirtle, C., R. Townsend, van Zyl, J. 1998. Testing the induced innovation hypothesis: an error correction model of South African agriculture. Agricultural Economics, 19, 145-157.

Thirtle, C. G. and V. W. Ruttan, 1987. The role of demand and supply in the generation and diffusion of technical change. Harwood Academic Publication, 173 pp. 
Thirtle, C., R. Townsend, van Zyl, J. 1998. Testing the induced innovation hypothesis: an error correction model of South African agriculture. Agricultural Economics, 19, 145157. 


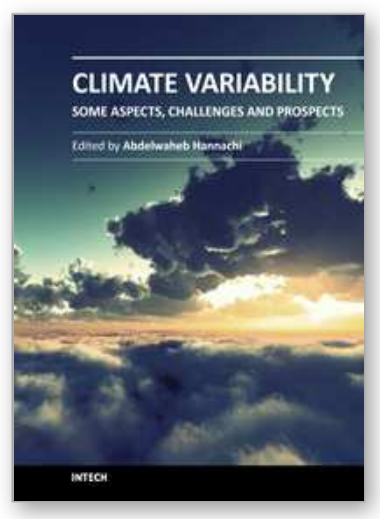

\author{
Climate Variability - Some Aspects, Challenges and Prospects \\ Edited by Dr. Abdel Hannachi
}

ISBN 978-953-307-699-7

Hard cover, 192 pages

Publisher InTech

Published online 18, January, 2012

Published in print edition January, 2012

This book provides a general introduction to the popular topic of climate variability. It explores various aspects of climate variability and change from different perspectives, ranging from the basic nature of low-frequency atmospheric variability to the adaptation to climate variability and change. This easy and accessible book can be used by professionals and non professionals alike.

\title{
How to reference
}

In order to correctly reference this scholarly work, feel free to copy and paste the following:

Netra B. Chhetri (2012). Adapting Agriculture to Climate Variability and Change: Capacity Building Through Technological Innovation, Climate Variability - Some Aspects, Challenges and Prospects, Dr. Abdel Hannachi (Ed.), ISBN: 978-953-307-699-7, InTech, Available from: http://www.intechopen.com/books/climate-variabilitysome-aspects-challenges-and-prospects/adapting-agriculture-to-climate-variability-and-change-capacitybuilding-through-technological-innov

\section{INTECH}

open science | open minds

\section{InTech Europe}

University Campus STeP Ri

Slavka Krautzeka 83/A

51000 Rijeka, Croatia

Phone: +385 (51) 770447

Fax: +385 (51) 686166

www.intechopen.com

\section{InTech China}

Unit 405, Office Block, Hotel Equatorial Shanghai

No.65, Yan An Road (West), Shanghai, 200040, China 中国上海市延安西路65号上海国际贵都大饭店办公楼 405 单元

Phone: +86-21-62489820

Fax: $+86-21-62489821$ 
(C) 2012 The Author(s). Licensee IntechOpen. This is an open access article distributed under the terms of the Creative Commons Attribution 3.0 License, which permits unrestricted use, distribution, and reproduction in any medium, provided the original work is properly cited. 